\title{
A MOUND FIELD IN THE SECOND SALPAUSSELKA ICE-MARGINAL BELT AT KURHILA, SOUTHERN FINLAND
}

\author{
Marjatta Okgo and Marjatta Perttunen
}

\begin{abstract}
Okgo, Marjatta and Perttunen, Marjatta 1971: A mound field in the Second Salpausselkä ice-marginal belt at Kurhila, southern Finland. Bull. Geol. Soc. Finland 43, 47-54.
\end{abstract}

\begin{abstract}
A dozen mounds, from $20 \mathrm{~m}$ to $100 \mathrm{~m}$ in diameter and $3 \mathrm{~m}$ to $5 \mathrm{~m}$ high, occur at the junction of two Late Weichselian ice lobes. One of the mounds, built of stratified silts and fine sands, is described in detail. In addition to the field evidence, its structure and granulometry show that this mound was deposited by meltwaters into a subglacial cavern in stagnant marginal ice. Some of the other mounds consist of washed till. They are believed to represent debris-filled sink-holes on the surface of the stagnant ice. The Second Salpausselkä ice-marginal belt thus contains dead-ice deposits that originated through karst formation in the ice.
\end{abstract}

Marjatta Okko and Marjatta Perttunen, Geological Survey of Finland, Otaniemi, Finland.

\section{Introduction}

In this paper is described a mound field that occurs in the Second Salpausselkä ice-marginal belt, at Kurhila, as a small yet morphologically distinct feature. In relation to the large outwash deposits there (see, e.g., Leiviskä 1920, pp. 137144; 1928, pp. 29-34, Map V, Pl. IV) the mounds, which vary from $20 \mathrm{~m}$ to $100 \mathrm{~m}$ in diameter and are $3 \mathrm{~m}$ to $5 \mathrm{~m}$ high, are miniature land forms. In his comprehensive monograph on the Salpausselkä belts, Leiviskä (1920, pp. 139 - 140, Fig. 92) described the mound field as »ein gewälltes Sandfeld, aus dem zahlreiche Hügelchen emporragen» (p. 139). He regarded this Hiugellandschaft as belonging to the ice- marginal facies but did not touch upon its genesis.

While mapping the Quaternary deposits of the Lammi map-sheet area in 1968, we made a special study of the mound field. The purpose of the present paper is to give an account of the results of our study, which led us to regard the mounds as a type of ice-marginal deposit not previously known to exist in Finland.

The geological maps reproduced in this paper are based on field work done by Marjatta Perttunen. She also did the granulometric analyses and interviewed the farmers to obtain information on the sediments exposed during diggings for wells. Marjatta Okko wrote the paper and is responsible for the conclusions. 


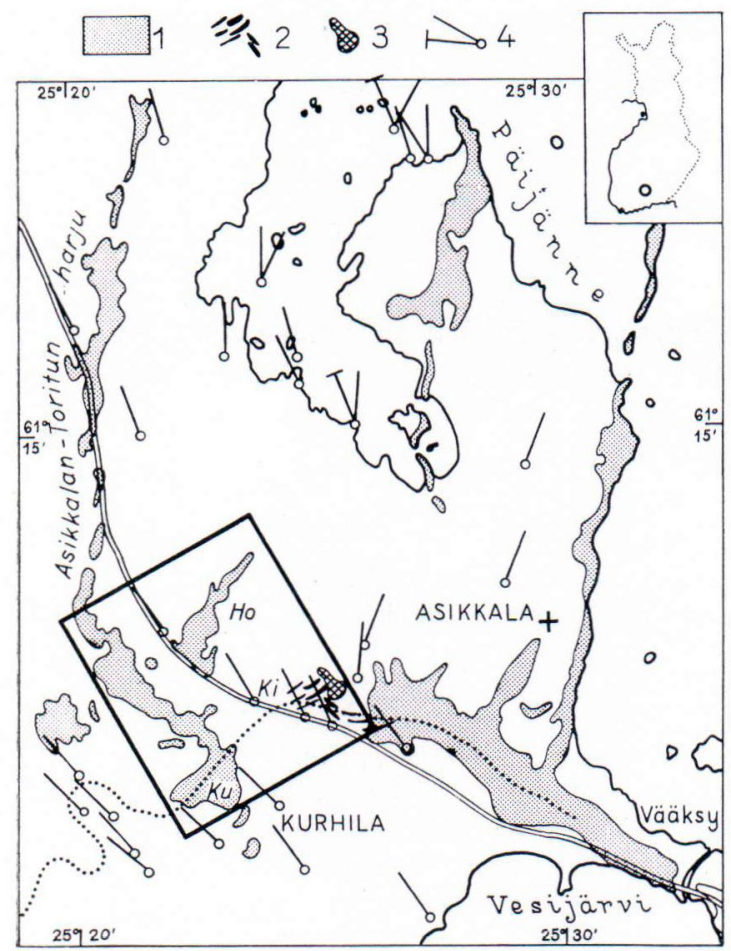

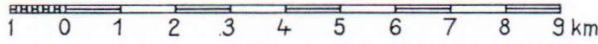

Fig. 1. Map showing the relation of the Kurhila area to the terminal and radial deposits around the bend of the Second Salpausselkä ice-marginal belt at the southern end of Lake Päijänne. 1, glaciofluvial accumulations; 2, end-moraine ridges; 3 , dead-ice moraine; 4 , glacial striae - circle denotes outcrop and the attached lines point upstream; the direction of older ice movement determined from crossing striae is marked with the cross-line. Ho, Honkalanharju; Ki, Kiikarmäki; Ku, Kurhila plateau. The watershed is marked with a dotted line.

\section{Geological outline}

The Kurhila area lies at the bend of the Second Salpausselkä ice-marginal belt where the wide eastern arc and the southwestern arc meet. The observations on glacial erosion together with the trends of the marginal and radial deposits show that the eastern flank of the bend represents the outer limit of an ice movement from the north and the north-northeast (Fig. 1; see also, Frosterus 1911, p. 22; Leiviskä 1920, p. 294). The northern movement postdated a northwestern ice movement. Its limit at the eastern flank of the bend is a local feature. Immediately east and southeast of the area shown in Fig. 1, the younger ice movement extended right across the Second Salpausselkä belt (see, Fogelberg 1970, p. 21).

The juncture of the two ice margins lies on top of a hill called Kiikarmäki (Ki in Fig. 1; $173.4 \mathrm{~m}$ above sea level). End moraines of both ice lobes occur there together with a portion of a dead-ice moraine.

The trend of the radial deposits shows that the northern ice extended somewhat farther west than the terminal juncture point. Of the eskers shown in Fig. 1, most were deposited within the sphere of the northern ice. The westernmost esker may be attributed to the northwestern ice. According to Leiviskä (1928, p. 179), it should have developed as a marginal continuation of the eastern arc of the Second Salpausselkä belt and it belongs to those eskers that were built either marginally or between two ice streams.

The Baltic Ice Lake B III (see, Donner 1969, p. 7, Fig. 4) extended to the ice margin at Kurhila. Its shore-line lies at $160 \mathrm{~m}$ above sea level there. The glaciofluvial deltas reach this altitude but do not show any supra-aquatic erosion features. The westernmost esker, called Asikkalan-Toritunharju by Leiviskä (1928, p. 29), is a direct continuation of a glaciofluvial delta, the Kurhila plateau of Leiviskä (1920, p. 138; $\mathrm{Ku}$ in Fig. 1). The tops of the esker are levelled to the 160-metre-level for a length of $5 \mathrm{~km}$, considered by Sauramo (1928, pp. 15-16) to show that esker deposition was controlled by the contemporaneous ice-lake level. The broad southwestern part of the esker next in the east, Leiviskä's (1920, p. 140; 1928, p. 43) Honkalanharju (Ho in Fig. 1), also has a level top surface at $160 \mathrm{~m}$. The other eskers shown in Fig. 1 do not reach this altitude.

The well-known Late Weichselian "landmark» in southern Finland is the drop of level from the Baltic Ice Lake III to the Yoldia Sea level. 

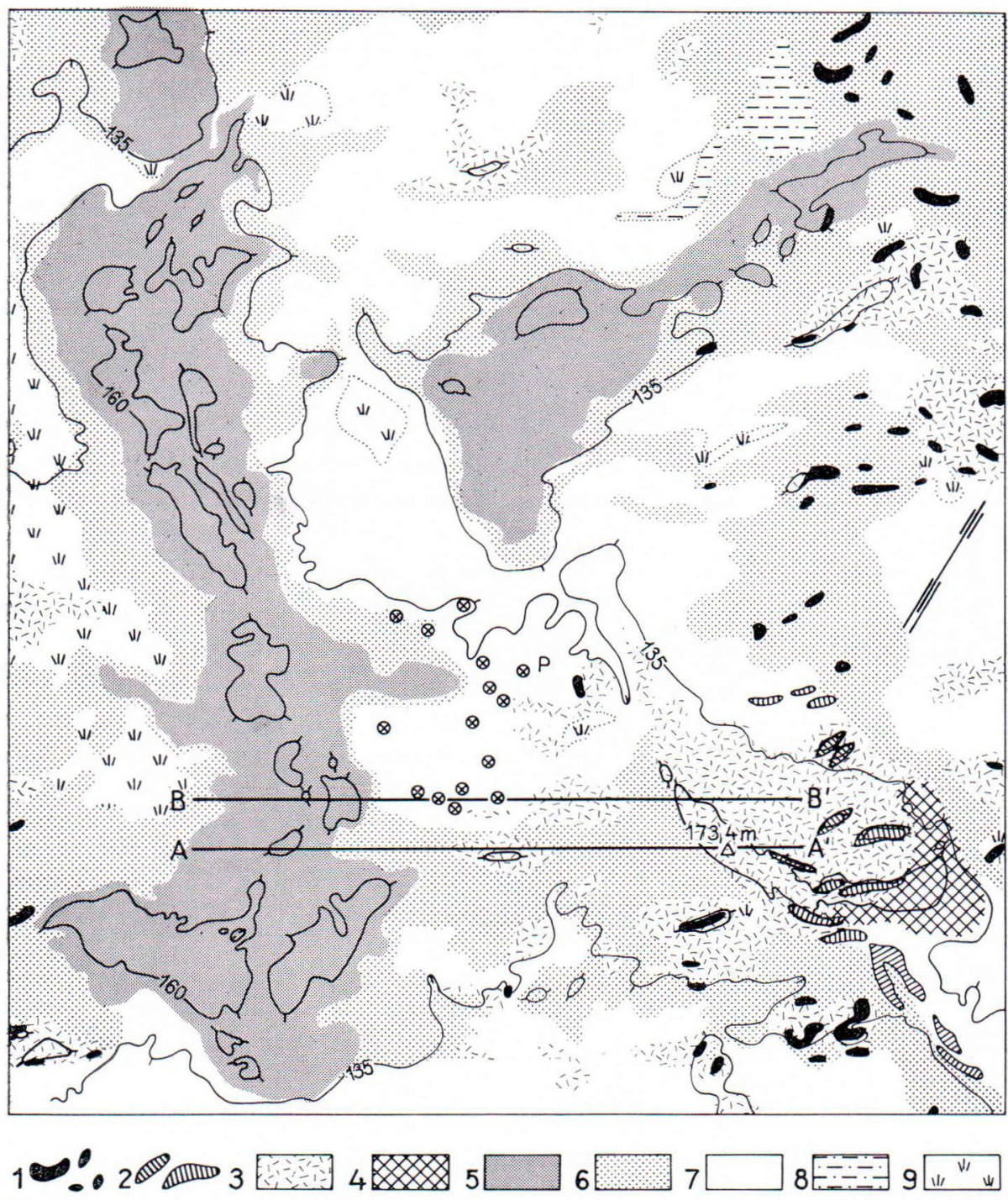

Fig. 2. Detail map of the mound field at Kurhila. Location is shown in Fig. 1. 1, outcropping bedrock; 2, end-moraine ridges; 3, ground moraine; 4, dead-ice moraine; 5, glaciofluvial accumulations; 6, gravels and sands, mostly redeposited; 7, fine sands, loams and silts; 8, glacial clay; 9, peats. Mounds are marked with circles; $\mathrm{P}$ is the mound at the Perttula farm house. The thicker contour line, $160 \mathrm{~m}$, corresponds to the level of Baltic Ice Lake III, whereas the thinner contour line, $135 \mathrm{~m}$, lies about $3 \mathrm{~m}$ above the Yoldia I level. The relief profiles of Fig. 3 were drawn along lines $A-A^{\prime}$ and $B-B^{\prime}$. Width of map equals to $4 \mathrm{~km}$.

The drop amounts to $26-28 \mathrm{~m}$. Judging by the top altitudes of the marginal and radial deposits in the Kurhila area, the northwestern ice margin wasted away before the northern ice withdrew from the Second Salpausselkä at the bend and also before the drop in the level.
The ice-marginal deposits in the Kurhila area coincide with the watershed between the waters drained into Vesijärvi and Päijänne. In the gap between the glaciofluvial accumulations of the northwestern and northern ice the watershed runs from the juncture at Kiikarmäki to the 


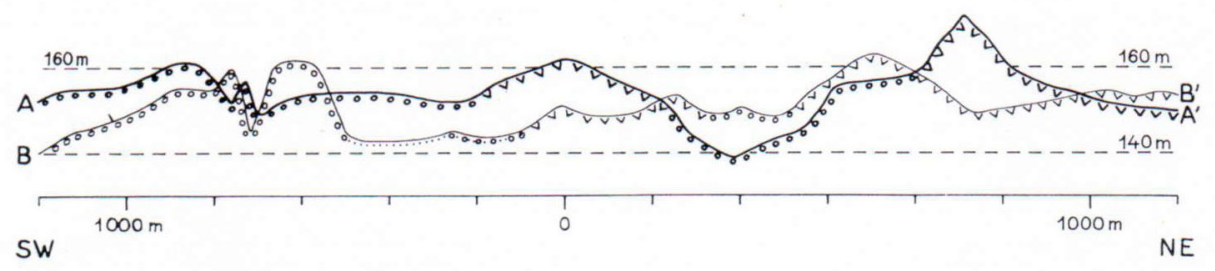

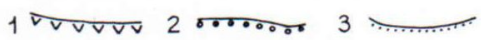

Fig. 3. Two relief profiles drawn along the watershed at the gap between the Kurhila plateau and the end-moraine juncture at Kiikarmäki. Location of the profile lines is shown in Fig. 2. 1, till; 2, esker material, gravel and sand; 3 , fine sand and loam. Height scale $10 \mathrm{x}$.

Kurhila plateau. Along this stretch the watershed is covered with till and overlying sandy shore deposits. It lies from $150 \mathrm{~m}$ to about $162 \mathrm{~m}$ above sea level. The bedrock surface has been encountered in two wells, at $140 \mathrm{~m}$ and $135 \mathrm{~m}$ above sea level. Leiviskä (1920, p. 139) regarded the watershed as the distal ridge of the Second Salpausselkä there. Possibly the till deposits are end moraines deformed by shore action. Their high position is due, however, to the high relief of the underlying bedrock.

The slope from the watershed toward the gap is gently rolling farm land (see also, Leiviskä 1920, profile 315). Deposits composed of silts, loams and fine sands cover the gap. Their thickness varies from $0.5 \mathrm{~m}$ to $8 \mathrm{~m}$; the median thickness based on interview data on 15 household wells is $4.5 \mathrm{~m}$. Till, gravel, or the bedrock surface underlie the sediments. The rolling topography is not, as Leiviskä noted, too, a relief form of the sediment cover: under it there are a number of mounds (see Fig. 2) built of till or glaciofluvial and glaciolacustrine sediments. The core material was verified in five mounds. In the north-west a ridge of outwash, perpendicular to the northwestern ice-movement direction, extends from the Asikkala-Torittu esker into the mound field. This ridge Leiviskä (1920, pp. 139-140, profile 316) considered to be the proximal ridge of the ice-marginal belt.

The mounds occur in the area of northwestern glacial sculpture within the Second Salpausselkä belt. They lie within the limits of $135 \mathrm{~m}$ and
$150 \mathrm{~m}$ above present sea level or below the level of the Baltic Ice Lake III at $160 \mathrm{~m}$ but higher than the level of the Yoldia Sea at $132 \mathrm{~m}$. The mound field was rather well sheltered from the shore action of the ice lake, as indicated by the two profiles showing the relief along the watershed in the gap (Fig. 3).

Shallow pits dug through the cover of fine sediments into four of the mounds reveal washed material rich in angular to sub-rounded rock fragments the size of pebbles and cobbles. The pit walls are too low to allow any structural observations. The only mound having a large enough cutting for the study of its interior structure is that at the Perttula farm house ( $\mathrm{P}$ in Fig. 2), where the mound rests directly on a moraine.

\section{The Perttula mound}

\section{Stratigrapby and structure}

The cutting at Perttula (Fig. 4) is $6 \mathrm{~m}$ long and it runs in a southwest-northeast direction or parallel to the southwestern flank of the Second Salpausselkä. Vertical faults divide the wall into three blocks. The slopeward blocks have moved down in relation to the inner block.

In the best-preserved inner block a sheet of loam, L, $1.2 \mathrm{~m}$ thick, forms the top bed. The upper part of the bed, $L_{1}$, does not exhibit any sedimentary structures - it is »massive» - but the lower part, $\mathrm{L}_{2}$, shows faint signs of crossbedding. The loams overlie a thin bed, $5 \mathrm{~cm}$, 
of graded silt, $\mathrm{S}_{1}$, which in its turn overlies cross-bedded fine sands, $C_{1}$. Bed $C_{1}$ is $40 \mathrm{~cm}$ thick. Its lowermost part, $2.5 \mathrm{~cm}$, is rather compact. Downwards the $\mathrm{C}_{1}$ bed grades over into fine sand intercalated with silt bands, $\mathrm{S}_{2}$. Under the $\mathrm{S}_{2}$ bed lies a deformed bed, $\mathrm{D}_{1}$. Its thickness varies from $25 \mathrm{~cm}$ to $40 \mathrm{~cm}$. Both the upper and lower limits of bed $D_{1}$ are clearly defined. Bed $\mathrm{D}_{1}$ is underlain by a bed of fine sands, $C_{2}, 20$ to $30 \mathrm{~cm}$ thick. This bed is partly laminated and partly cross-bedded in structure. In places its base is strongly laminated, rich in mica flakes and, in spots, mottled with grains about $2 \mathrm{~mm}$ in diameter; in other places the bed grades over into the underlying bed, $\mathrm{D}_{2}$, which is strongly deformed. The cutting has not been extended down to the base of the beds.

Bed $D_{1}$ shows a folded structure. In the better-preserved synclines, thin cross-bedded laminae are discernible between laminated layers finer in grain. The anticlines are sharp-edged while the synclines are broad. The anticlines point away from the centre of the mound. The fold-axis directions are parallel to the slope of the mound and they lie quite flat, $20^{\circ}$ to $0^{\circ}$. In some places the deformation seems to have been plastic, while elsewhere dense shearing is associated with the deformation. Because the deformation is confined to only one bed, conformably overlain by laminated silt and fine sand, the slump structures seem to be due to a metadepositional rearrangement within the total bed.

In the $\mathrm{D}_{2}$ bed the deformation structures are a mash of plastically deformed strata. In places the lower part of the overlying $\mathrm{C}_{2}$ bed is also disturbed and silt pipes extend from bed $D_{2}$ into bed $\mathrm{C}_{2}$. In the vicinity of the silt pipes, microfaults occur in bed $\mathrm{C}_{2}$. The deformation of bed $\mathrm{D}_{2}$ is at least partly postdepositional.

Not all the deformations are confined to the $\mathrm{D}$ beds. Associated with the major fault limiting the inner block, a shear fold was observed in the uppermost part of bed $\mathrm{C}_{2}$ in the inner block.

\section{Granulometry}

All the beds occurring in the inner block were sampled and their grain-size distributions analyzed. The analytical results are shown in Fig. 5 as cumulative distribution curves. There is a distinct correlation between the structures and the granulometry.

The $\mathrm{L}$ beds consist of loams with the median grain size, $\mathrm{M} d$, of $\mathrm{L}_{1}$ at $0.06 \mathrm{~mm}$ and at $0.07 \mathrm{~mm}$ of $\mathrm{L}_{2}$. The values of the sorting coefficient, $\mathrm{S}_{0}=\sqrt{\mathrm{Q}_{3} / \mathrm{Q}_{1}}$, are 1.74 and 1.88 , respectively.

The massive structure of the better sorted $\mathrm{L}_{1}$ bed may have been caused by the roots of trees in the course of time. To some extent, the loams, $\mathrm{L}_{1}$ in particular, may be eolian in origin, as there are abundant occurrences of eolian deposits - dunes and cover sands - at the foot of the Kurhila plateau (see, Leiviskä 1920, Fig. 91) and west of the Asikkala-Torittu esker. Also the

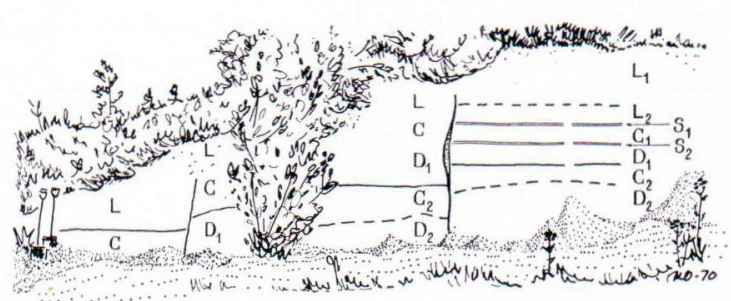

Fig. 4. Cutting in the Perttula mound. Sketch is drawn according to photographs and field observations. L, loams; S, beds rich in silt; $\mathrm{C}$, fine sands, mainly crossbedded; D, deformed beds. Detailed description in text. Greatest height of the cut wall is $2.7 \mathrm{~m}$.

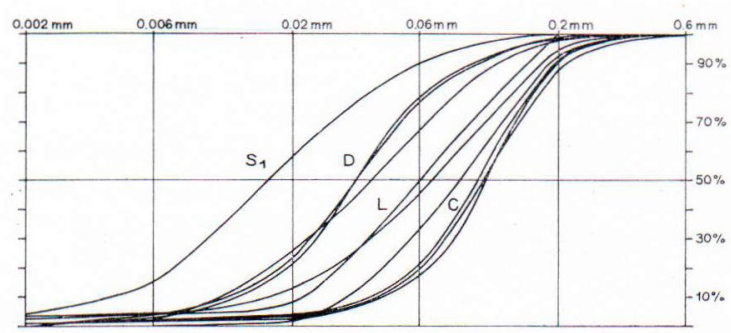

Fig. 5. Cumulative grain-size distribution curves of the sediments exposed in the cutting at Perttula. Letters as in Fig. 4. 
granulometric composition (50\% fine sand, $42 \%$ coarse silt, and $8 \%$ fines), together with the complete lack of grains larger than $0.2 \mathrm{~mm}$ in diameter, points to eolian transportation beyond the dune fields proper.

The Md of the sample analyzed of the graded $\mathrm{S}_{1}$ bed is $0.016 \mathrm{~mm}$. The skewness value 1.0 indicates a symmetrical frequency distribution of the grains. Owing to the graded structure, the value of the sorting coefficient $S_{0}$ is relatively high, 1.97. The laminated $S_{2}$ bed is composed of fine sand $(0.06 \mathrm{~mm}-0.2 \mathrm{~mm})$ and medium silt $(0.006 \mathrm{~mm}-0.02 \mathrm{~mm})$, their mutual ratio depending on the sampling of the laminated bed. The $\mathrm{S}_{0}$ is of the order 3 . Bed $\mathrm{S}_{2}$ is not represented in Fig. 5.

The cross-bedded $\mathrm{C}$ beds are fine sands. Their $\mathrm{M} d$ ranges from $0.085 \mathrm{~mm}$ to $0.105 \mathrm{~mm}$. The sorting is very good: $\mathrm{S}_{0}$ from 1.41 to 1.66 .

The median grain size, $\mathrm{M} d$, of the samples representing the two $\mathrm{D}$ beds is from $0.035 \mathrm{~mm}$ to $0.04 \mathrm{~mm}$. The sorting coefficient $S_{0}$ is from 1.57 to 1.92 . The $\mathrm{D}$ beds are less well sorted than the $\mathrm{C}$ beds with which they alternate. The skewness of the grain distributions of the $\mathrm{C}$ and $\mathrm{D}$ samples is of the same order, $0.88-0.98$, but the kurtosis coefficient, $\mathrm{K}=\left(\mathrm{Q}_{3}-\mathrm{Q}_{1}\right): 2\left(\mathrm{P}_{90}-\right.$ $P_{10}$ ), is for the $\mathrm{D}$ group from 0.194 to 0.239 , or definitely smaller than for the $\mathrm{C}$ group, with its figures from 0.236 to 0.276 . In addition to the richness in coarse silt, also the narrow distribution of grain sizes between the quartiles of the D material made the D beds structurally labile. A rearrangement of the initial depositional structure was apt to take place as soon as the sedimentological conditions changed.

\section{Interpretation}

The Perttula mound represents a sedimentary sequence in which the sedimentological conditions varied from stream currents (C beds) to standing water ( $\mathrm{S}$ beds) with a probable final change into eolian deposition either on dry land or in water ( $\mathrm{L}$ beds). The values of the sorting coefficient $S_{0}$ of the different samples are in accordance with this interpretation. The $\mathrm{S}_{0}$ values, $1.41-1.66$, of the $C$ beds agree with the median of the $S_{0}$ of the fine sand material in the Tana river valley, northernmost Finland (Mansikkaniemi 1970, p. 52). According to Köster (1960, p. 142) the $S_{0}$ of the Central European flood sediments and sediments deposited in standing water exceeds 2 ; the $\mathrm{S}_{\mathbf{0}}$ is 1.97 in the graded and about 3 in the laminated $S$ beds. Furthermore, in Central Europe, the $\mathrm{S}_{0}$ of loesses exceeds 1.4. Although no true loesses, the $\mathrm{L}$ samples show a similar trend, $\mathrm{S}_{0} 1.74-$ 1.88 .

Because of the homogenization processes that have taken place in the $\mathrm{D}$ beds, their initial depositional conditions are more difficult to trace. The preserved cross-bedded laminae within laminated siltier layers in bed $D_{1}$ suggest alternating changes in the flow of water. The $S_{0}$ values of the D samples, 1.57-1.92, could indicate such changes. Noteworthy in this connection are the differences in $\mathrm{S}_{0}$ of river sands in regulated and unregulated rivers in Central Europe. The $S_{0}$ of the latter range from 1.3 to 1.9 , whereas it stays within the limits of 1.2 and 1.3 in the former (Köster 1960, p. 142). At any rate, the sharp bed boundaries $C_{2} / D_{1}$ and $D_{1} / S_{2}$ mark discontinuities in the sedimentation.

Deformations took place in at least three stages. The deformation of bed $\mathrm{D}_{2}$ and the lower part of bed $\mathrm{C}_{2}$ may have resulted purely from the load on the labile bed $\mathrm{D}_{2}$ by the thickening bed $C_{2}$ in association with a change from primarily standing to streaming water. The possibility that this deformation is a frost structure cannot be ruled out: the discontinuity on top of bed $C_{2}$ may have allowed freezing and thawing out of beds $\mathrm{D}_{2}$ and $\mathrm{C}_{2}$.

The second deformation was confined to bed $D_{1}$. The combination of sheared and plastic slumping may be attributed either to a sedimentological change during the interval $\mathrm{D}_{1} / \mathrm{S}_{2}$ or to freezing and thawing out during the same interval. 
During the third stage of deformation the sequence was faulted into vertical blocks. The faults cannot be traced in the massive $\mathrm{L}$ beds. The fault limiting the inner block has a filling of fine sand. This may indicate a post- $\mathrm{C}_{1}$ and pre- $\mathrm{L}$ faulting although not necessarily so, because the sand grains of bed $\mathrm{C}_{1}$ would in any event slide easier into the opening fault than the top loams. The transverse shear fold and other transverse microfaults close to the vertical major fault indicate that the materials responded rather rigidly to the faulting. Most probably it took place to normalize the slope of the mound.

\section{Discussion and conclusions}

It is quite possible that some of the till mounds that occur in pairs are exposures through the sediment cover of one and the same mound which, then, could be rimmed in shape. The till mounds would be morphologically analogous to the prairie mounds of western Canada, interpreted by Gravenor (1955) to have originated as debris-filled pits on a stagnant ice surface. The seemingly disordered stony outwash observed in four mounds is similar to the washed tills that M. Okko has found in the dead-ice moraines covering the Evo heights, west of Kurhila.

The fact that outwash materials are relatively scarce on the Canadian prairies (e.g., Gravenor 1955; Gravenor and Kupsch 1959) does not necessarily exclude the formation of pit mounds in areas rich in outwash materials. Gravenor (1955) stressed that, in east-central Alberta, the formation of prairie mounds is connected with the retreat of the ice in a downslope direction. This condition prevailed also in the mound field of Kurhila, though only on a small scale. Furthermore, according to Gravenor, under conditions of downslope retreat, lakes would form in front of the ice and a water table would be built up in the stagnant marginal ice; this would lead to the formation of solution caves and hence mounds. In the Kurhila area the
Baltic Ice Lake extended to the ice margin. If there had been stagnant ice behind the watershed in the gap, a water table would have formed in it and the water would have permeated the lowermost $10 \mathrm{~m}$ to $25 \mathrm{~m}$ of the ice. This ground-water base level would have caused glacial karst to form in the stagnant marginal ice ( $c f$., Clayton 1964 , p. 108). Owing to the differences in the relief of the solid bottom under this ice, caving at the water-table level would have led also to the formation of caves and caverns bottomed on solid ground. Not much uplifting of the ice would have taken place because the dead-ice block was sheltered from direct shore action by the high middle part of the watershed (Fig. 3).

According to Sundborg (1967, p. 337), fine sand composed of quartz and feldspar is transported as suspended load when the flow velocity $1 \mathrm{~m}$ above the bottom exceeds $4 \mathrm{~cm} / \mathrm{sec}$ for the $0.06 \mathrm{~mm}$ grains and $25 \mathrm{~cm} / \mathrm{sec}$ for the $0.2 \mathrm{~mm}$ grains. Below these velocities there is no transport of fine sand. The velocity of the waters carrying the $\mathrm{C}$ load into the sedimentary sequence at Perttula was thus quite slow. Obviously, it was a normal river, under atmospheric pressure, that upstream had access to fine sand.

The foregoing considerations allow a genetical interpretation of the Perttula mound. Provided that a subaerial tunnel leads to a cavern and another tunnel away from it, a subglacial cavern in dead ice can serve as a basin for sedimentation of ice-lake sediments. They are represented in the Perttula sequence by the $\mathrm{S}$ beds and probably by a substantial part of the $\mathrm{D}$ bed materials. The $\mathrm{C}$ beds were deposited by slowly running water carrying a load of fine sand. This implies some distance of transport; the distance of $5 \mathrm{~km}$ from the proximal end of the part of the AsikkalaTorittu esker controlled by the Baltic Ice Lake is certainly sufficient.

Clayton (1964) described the karst topography of the Martin River Glacier in Alaska. In the stagnant marginal portions of that glacier, there are exposed caverns bottomed on solid ground and floored with lake sediments or outwash. 
A stream may flow into them and continue into another tunnel at the other side. A stratigraphical sequence similar to that of the Perttula mound should result from such sedimentary conditions. In the same glacier there are funnel-shaped sinkholes which, in Clayton's opinion, represent the initial stage of the formation of till mounds.

In the Scandinavian glaciated region, the plateau-lerbakkerne or plateau-like clay hills of Denmark, generally regarded as ice-lake sediments deposited within dead ice (see, Milthers 1948 , p. 54), are the nearest counterparts of the Perttula mound known to the authors. Gravenor and Kupsch (1959, p. 51) refer to the analogy between the Danish hills and the plateaus built of stratified silts and sands in the dead-ice moraines of western Canada.

The Perttula mound developed through deposition of glacial lake and stream sediments in a subglacial cavern formed into stagnant marginal ice. The mounds consisting of dead-ice till probably originated as debris-filled sinkholes on the surface of the stagnant ice. The high bedrock relief prevented the dead-ice block from floating away. The Second Salpausselkä ice-marginal belt thus contains dead-ice deposits that originated through karst formation.

Acknowledgment - Marjatta Okko gratefully acknowledges the research grant awarded to her in 1969 by the State Board for Scientific Research.

\section{REFERENCES}

Clayton, Lee (1964) Karst topography on stagnant glaciers. J. Glaciol., Vol. 5, pp. 107-112.

Donner, J. J. (1969) A profile across Fennoscandia of Late Weichselian and Flandrian shore-lines. Soc. Scient. Fennica. Comment. Phys.-Math., Vol. 36, No. 1. 23 p.

Fogelber G, Paul (1970) Geomorphology and deglaciation at the Second Salpausselkä between Vääksy and Vierumäki, southern Finland. Soc. Scient. Fennica. Comment. Phys.-Math., Vol. 39. 90 p.

Frosterus, BenJ. (1911) Beskrifning till jordartskartan C 2, S:t Michel. Résumé en français. [General Geological Map of Finland, $1: 400$ 000].

Gravenor, C. P. (1955) The origin and significance of prairie mounds. Amer. J. Sci., Vol. 253, pp. 475-481.

Gravenor, C. P., and Kupsch, W. O. (1959) Icedisintegration features in western Canada. J. Geol., Vol. 67, pp. 48- 64.

Köster, Erhard (1960) Mechanische Gesteins- und Bodenanalyse; Leitfaden der Granulometrie und Morphometrie. Carl Hanser Verlag, München. 171 p.
LeIviskä, I. (1920) Der Salpausselkä. Fennia 41, No. 3 $388 \mathrm{p}$.

- (1928) Über die Ose Mittelfinnlands; die Entstehung des Materials und der Formen der Ose. Fennia 51, No. 4. 207 p.

Mansikmaniemi, Hannu (1970) Deposits of sorted material in the Inarijoki-Tana river valley in Lapland. Rep. Kevo Subarctic Research Station, 6. 63 p. Also Ann. Univ. Turku., Ser. A, II, 43.

Mrtthers, V. (1948) Det danske istidslandskabs terrænformer og deres opstaaen. Summary: The morphology and genesis of the glacial landscape in Denmark. Danmarks Geol. Unders., III Rk., No. 28. 234 p.

Sauramo, Matti (1928) Über das Verhälnis der Ose zum höchsten Strand. Fennia 51, No. 6. 16 p. - Also Bull. Comm. Géol. Finlande No. 84.

Sundbor G, $\AA_{\text {Ke }}$ (1967) Some aspects on fluvial sediments and fluvial morphology, I. General views and graphic methods. Geogr. Ann., Vol. 49 A, pp. 333-343.

Manuscript received, April 14, 1970. 